\title{
The Effect of Understanding Codes of Ethics and Independence upon the Ethical Judgement and Personal Value as an Intervening Variable
}

\author{
Yuli Anwar, ${ }^{1,}$, Sukrisno Agoes ${ }^{2}$, Muhammad Nuryatno Amin ${ }^{3}$, Antonius Herusetya ${ }^{4}$ \\ ${ }^{1}$ Department of Accounting, Economic College of Binaniaga, Bogor, Indonesia \\ ${ }^{2}$ Department of Accounting, Tarumanagara University, Jakarta, Indonesia \\ ${ }^{3}$ Department of Accounting, Trisakti University, Jakarta, Indonesia \\ ${ }^{4}$ Department of Accounting, Pelita Harapan University, Jakarta, Indonesia
}

Email address:

juli_anwar@yahoo.com(Y.Anwar),sukrisno.a@gmail.com(S. Agoes), nanotrisakti@gmail.com(M. N. Amin), aherusetya@yahoo.com(A. Herusetya)

${ }^{*}$ Corresponding author

\section{To cite this article:}

Yuli Anwar, Sukrisno Agoes, Muhammad Nuryatno Amin, Antonius Herusetya. The Effect of Understanding Codes of Ethics and Independence upon the Ethical Judgement and Personal Value as an Intervening Variable. American Journal of Theoretical and Applied Business. Vol. 4, No. 1, 2018, pp. 8-14. doi: 10.11648/j.ajtab.20180401.12

Received: January 23, 2018; Accepted: February 8, 2018; Published: February 28, 2018

\begin{abstract}
This research aims to examine the effect of understanding codes of ethics (uce) and independence (i) upon the ethical judgement (ej) thru the personal value (pv) of the public accountant. Data collected using purposive sampling and total of the samples is 301 respondents of accountants in Indonesia. The constructs which have been directly affected one to another in this research is uce and i upon pv; uce, $i$ and pv upon ej. However, there has been any direct effect of the accountants in Indonesia occurred upon their pv against ej accordingly. The model offered has indicated the impact of uce, $i, p v$ and ej. Accountants in Indonesia might have made more discreet decision thru the ethical judgement based on the actual facts. The resulted a direct effect of uce and i upon pv; uce, $i$ and pv upon ej, however, there are direct effect of the understanding codes of ethics and independence has happened to the personal value upon the ethical judgement.
\end{abstract}

Keywords: Understanding of Codes of Ethics (uce), Independence (i), Personal Value (pv), Ethical Judgement (ej)

\section{Introduction}

The scandals had been done by the biggest public accountant in the world, Arthur Andersen has jeopardized and decreased even eliminated the people trust upon moral, personal value, ethics and independence of public accountant. The failure of Athur Andersen has vanished the people trust upon the honesty and standard of professional ethics (Coleman, Kreuze and Langsam, 2004).

Recent business evolvement has required public accountant to deal with the ethical dilemma which is sometimes involving the value of the ethics. The ethical dilemma refers to setting auditing, it could happen when the public accountant had disagreed with the client requirement regarding the functional aspects and the objective of an audit.
In this case, public accountant can be influenced by the client to perform a serial of auditing execution which is against the auditing standard. But, as a matter of fact, since public accountants have been following the professional ethics and auditing standard, they will be put into a conflict situation performing their tasks accordingly. It means when they should have to be agreed with the client requirement, they had broken the auditing standard regulation. Nevertheless, when they did not follow the client request, they would receive a serious sanction which is stopping the job (Muawanah and Indriantoro, 2001).

Once the importance of ethical judgment for a public accountant makes the issue interesting to examine as submitted by Kusuma (2003) that judgment is the most prominent issue in the development of BRIA (Behavioral Research in Accounting). Some cases of internal and foreign 
fraud involving public accountants encourage auditing behavior in the field of auditing should continue to be done along with the decline in public confidence in the independence of public accountants.

The originality of this study used independent variables understanding code of ethict and independence, and personal value as an intervening variable (exogenous). Meanwhile, ethical judgment as a variable dependen (endogenous), based on some of previous research who studies on ethical judgment, strengthen of this study are (1) no one has linked or used independence of public accountants as a variable that carries out direct to ethical judgment; (2) no one has linked or used the independence of a public accountant as a variable affecting personal value directly; (3) previous research has not considered personal value as intervening variable in estimating of understanding code of ethic public accountant to ethical judgment: and (4) Previous research has not considered personal value as intervening variable in estimating variable of public accountant independence to ethical judgment, because in some previous research personal value have direct influence to ethical judgment. The motivation of this research is to know, test, analyze, and prove empirically the widespread impact of violation of professional ethics conducted by public accountant to make ethical consideration problem as an interesting issue to be discussed, studied, analyzed and empirically proven factors influencing ethical judgment of public accountant in giving opinion.

\section{Literature Review}

\subsection{Ethical Judgement}

The ethical judgement of public accountant is obviously an important role of the accountancy skills implementation. Public Acccountants have been usually encountering an ethical dilemma when they have to deal with a doubtful ethical judgement refers to the standard of moral and ethical judgement of their own affecting their judgement and behavior (Jones, 1991). Wrigth, Cullinan, and Bline (1997) have investigated the preferences of public accountant value and their research has been in compliance with the hypothesis determined which is the effect of the value of moral intensity.

Shafer, Morris, dan Ketchand (2001) targeted public accountant in their research related to the effect of personal value upon the ethical decision making. The research has determined that the personal value of public accountant has not influenced the way how public accountants handling the problem of ethical dilemma (including the pressure from the clients). Some studies have discussed the same problems, but they have not considered the effect of moral philosophy and social responses accordingly. (Wrigth et al., 1997; Shafer et al., 2001; Karacaer, Gohar, Aygun, dan Sayin, 2009).

The research done by Kung and Huang (2013), defined that the preference of the value has failed to be a predictor of ethical beliefs. On the contrary, personal value has affected the ethical beliefs thru moral philosophy. Morever, accountants have been motivated by the value of negative self-improvement related to ethical idealism and the positive one related to relativism. Therefore, it can be concluded that the idealist accountants have tended to curse the clients who have broken moral norms, but relativist ones have been more permissive.

Wiratama and Budiartha (2015), described that accountants having an opini upon the reliability of the financial report are obliged to be independent on behalf of all related parties requirements. The accountants should have to be honest either to the internal or external party relying on the financial report audited. The independent accountant is very crucial to be respected, because once the client had not trusted the auditing report done by an auditor, the client or third party would ask no more further assistance from the related auditors. As it is stated in the Codes of Ethics of Professional Public Accountant, an accountant is obliged to respect the codes of ethics and to get rid of any misperception of the people regarding the independence of public accountant. People opinion regarding the accountant independence are due to an intrinsic independence related to the personal value instead of the regulation regulated and evaluated objectively. As long as this kind of independence perception is within the professional codes of ethics, it will make accountants to execute their tasks as independent as possible according to the professional regulation.

\subsection{Codes of Ethics}

Nur, Julita, and Wahyudi (2014), determined that nowadays, the accountants who have implemented the professional codes of ethics having good competency and experience, their opinions are reliable. However, the audit situation has not had any significant connection with the truth of the opinion provided. In Indonesia, the issues regarding the accountant ethics have been come up in line with some ethics violations happened due to either being done by public accountant, internal accountant or administrative accountant. Such a behavior is not in compliance with the professional accountant codes of ethics that should not have to be happened since it is jeopardizing the people trust upon the professional accountants.

Booth and Schulz (2004), discovered that strengthening the codes of ethics has been affecting significantly the manager behavior. However (Brief, Dukerich, Brown, and Brett, 1996) determined that no any significant effect of codes of ethics would happen if it had been applied without reinforcement effort. Pflugrat, Bennie, dan Chen (2007) identified that the existence of codes of ethics has affected positively upon the judgement quality done by public accountant. Moreover, previous researchs about codes of ethics have identified that codes of ethics has influenced absolutely the auditor's ethical judgement. (Jones, J; Massey, D.W; and Thorne, L, 2003; Herron and Gilbertson, 2004).

H1: The understanding codes of ethics influence on personal value

\subsection{Independence}

According to the American Institute Certified Public Accountant (AICPA, 2015), defines independence, namely: 
1. Independence of mind is the state of mind that permits a member to perform an attest service without being affected by influences that compromise professional judgement, thereby allowing an individual to act with integrity and exercise objectivity and professional skepticism.

2. Independence in appearance is the avoidance of circumstances that would cause a reasonable and informed third party, who has knowledge of all relevant information, including safeguards applied, to reasonably conclude that the integrity, objectivity, or professional skepticism of a firm or member of the attest engagement team is compromised.

Ashbaugh, Lafond and Mayhew (2003), conducted a study on non-audit services by independent accountants found no evidence to support claims that accountants violated the principle of independence caused by audit clients having paid large fees or because of non-audit fee ratios which is greater than the audit fee. This is in contrast to Krishnamurthy, Zhou, and Zhou (2002) research which states that the large amount of non-audit fees will affect the independence of accountants.

Brooks and Dunn (2014: 143), unanticipated by the AICPA special committee (AICPA) for verification services is the inability of its members to manage conflicts attached to situations of conflict of interest arising during the audit process and other services offered to clients same. Failure like this is one of the causes of the disaster that befell Enron, Arthur Andersen, and WorldCom.

$\mathrm{H} 2$ : The Indepenedence fluence on personal value

\subsection{Personal Value}

The research done by Akaah and Lund (1994) and Finegan (1994) declared that there is not any significant effect happened between the personal value and the ethical judgement refers to the organizational context. However, the research done by Au and Wong (2000), Abdolmohammadi and Baker (2006), indicated that a significant effect between personal value and ethical judgement has happened accordingly. Alteer, Yahya, dan Haron, (2013), has revealed that some models of ethical theory have provided a significant understanding about the ethical issues and some factors influencing the ethical judgement. The other model is accountant ethical judgement which has been influenced by personal value thru the sensitivity of ethics. However, the effect of personal value on the ethical sensitivity is expected to be stronger at the level of ethical climate. Nevertheless, Shafer, et al., (2001) defined that the preferences of personal value did not absolutely affect the perception of public accountant refers to moral intensity of ethical dilemma.

In reference with the discrepancies of the previous researchs done by some researchers such as Nur et al. (2014) determined that the more respect to the codes of ethics happened, the more accurate opinion would be; Booth and Schulz (2004) determined that restrengthening codes of ethics has been producing a significant impact; Pflugrath et al. (2007) declared that the existence of codes of ethics has positively affected the quality of judgement, Jones, et al, (2003); Herron and Gilbertson (2004) determined that an ethics can influence the auditor's ethical judgement, and Brief, et al. (1996) determined that there is not any significant effect happened when codes of ethics had been introduced without using a reinforcement effort. Akaah and Lund (1994) and Finegan (1994) determined that there has not been any significant effect happened between the personal value and the ethical judgement, Au and Wong (2000); Abdolmohammadi and Baker (2006) indicated a significant effect has happened between personal value and ethical judgement, Alteer, et al, (2013) indicated that the ethical judgement of an accountant has been affected by personal value thru ethical sensitivity, and Shafer, et al, (2001), determined that the preference of personal value has not affected the perception of public accountant.

However, nowadays there are so many ethical violations have been occurred either they have been conducted by public accountant, internal accountant, government accountant or the offices of public accountant, so that, this research aims to make over the related discrepancies by studying either a direct effect or an indirect effect of the understanding codes of ethics upon the ethical judgement intervened by the personal value.

H3: The understanding codes of ethics, independence, personal value and influence to ethical judgement

\section{Method}

\subsection{Sample and Procedure}

Samples selection of this research has been done gradually. First step is finding out the location of the research. The location of the research has been done at the big five of the cities in Indonesia which is Jakarta, Bandung, Medan, Semarang and Surabaya by considering as follows; Firstly, those big five of the cities have 367 offices of public accountant (KAP) (Jakarta = 258 , Bandung $=30$, Medan $=19$, Semarang $=17$, and Surabaya $=43)$ or $69.90 \%(367 / 525)$ of the total KAP in Indonesia registered in the Directory of the Indonesian Public Accountant in 2016. Secondly, it is related to the total of the partners, managers, supervisors and senior auditors at those five cities which have considerably represented the partners, managers, supervisors and senior auditors in Indonesia. Thirdly, limitation of time and cost consumed is the problem of the writer to face reaching all the area of the research.

Second step of sampling selection is to decide the total of the samples. Defining the total of the samples is based on the size of the samples required refers to the data analysis applying a structural equation model. Referring to Ghozali (2013) total of the samples required is the maximum likelihood estimation using structural equation model which is between 200 to 400 respondents. Based on the aforementioned guideline, the total of the samples required is between 200 to 400 respondents. The samples selected are in compliance with the related requirement representing the population accordingly.

Furthermore, sampling collection has been using the method of purposive sampling. This method has been chosen due to, (1) samples of the research are having the status as partners, 
managers, supervisors, and senior auditors, (2) total offices of public accountant in Indonesia are centralized at some big cities only which is Jakarta (49.14\%), Bandung (5.71\%), Semarang (3.24\%), Surabaya (8.19\%) and Medan (3.62\%).

\subsection{Data Analysis}

Data analysis of this research has applied structural equation model (SEM) refers to Lisrel 8.72 data analysis. The structural equations of flow diagram model of personal value and ethical judgement are as follows:

$$
\eta_{1}=\gamma_{1.1} \xi_{1}+\gamma_{1.2} \xi_{2}+\zeta_{1}
$$

or Personal Value $=\gamma_{1.1}$ uce $+\gamma_{1.2}$ i $\zeta_{1}$

$$
\eta_{2}=\gamma_{2.1} \xi_{1}+\gamma_{2.2} \xi_{2+} \beta_{2 \cdot 1} \eta_{1}+\zeta_{2}
$$

or Ethical Judgement $=\gamma_{2.1}$ uce $+\gamma_{2.2} i_{+} \beta_{2 \cdot 1} p v+\zeta_{2}$

According to the aforementioned equations, two models of the measurement of exogen latent variables $\xi_{1}$ and $\xi_{2}$ and three models of the measurement of endogen latent variable which is from the indicator to latent variable $\eta_{1}$, and $\eta_{2}$ have been made. The value of loading factor which is from the indicator to latent variable is named lamda $(\lambda)$.

\section{Result}

\subsection{Descriptive Statistic}

\begin{tabular}{|c|c|c|c|c|c|c|c|c|c|c|c|c|c|c|}
\hline Age & Sample & $\%$ & Sex & Sample & $\%$ & Education & Sample & $\%$ & Experience & Sample & $\%$ & Status & Sample & $\%$ \\
\hline$<=30$ years old & 63 & 20,9 & Male & 176 & 58,5 & Phd & 5 & 1,7 & $<5$ years old & 119 & 39,5 & Partner & 57 & 18,9 \\
\hline $31-40$ years olde & 67 & 22,3 & Female & 125 & 41,5 & Master & 51 & 16,9 & $5-10$ years old & 105 & 34,9 & Manager & 29 & 9,6 \\
\hline $41-50$ years old & 154 & 51,2 & & & & Bachelor & 242 & 80,4 & $11-20$ years old & 51 & 16,9 & Supervisor & 35 & 11,6 \\
\hline$>50$ years old & 17 & 5,6 & & & & Diploma & 3 & 1 & $>20$ years old & 26 & 8,7 & Senior Auditor & 180 & 59,9 \\
\hline Total & 301 & 100 & Total & 301 & 100 & Total & 301 & 100 & Total & 301 & 100 & Total & 301 & 100 \\
\hline
\end{tabular}

Table 1. Descriptive statistics for all respondent.

Based on the statistical result using Lisrel 8.72, it is described on figure 1 here below:

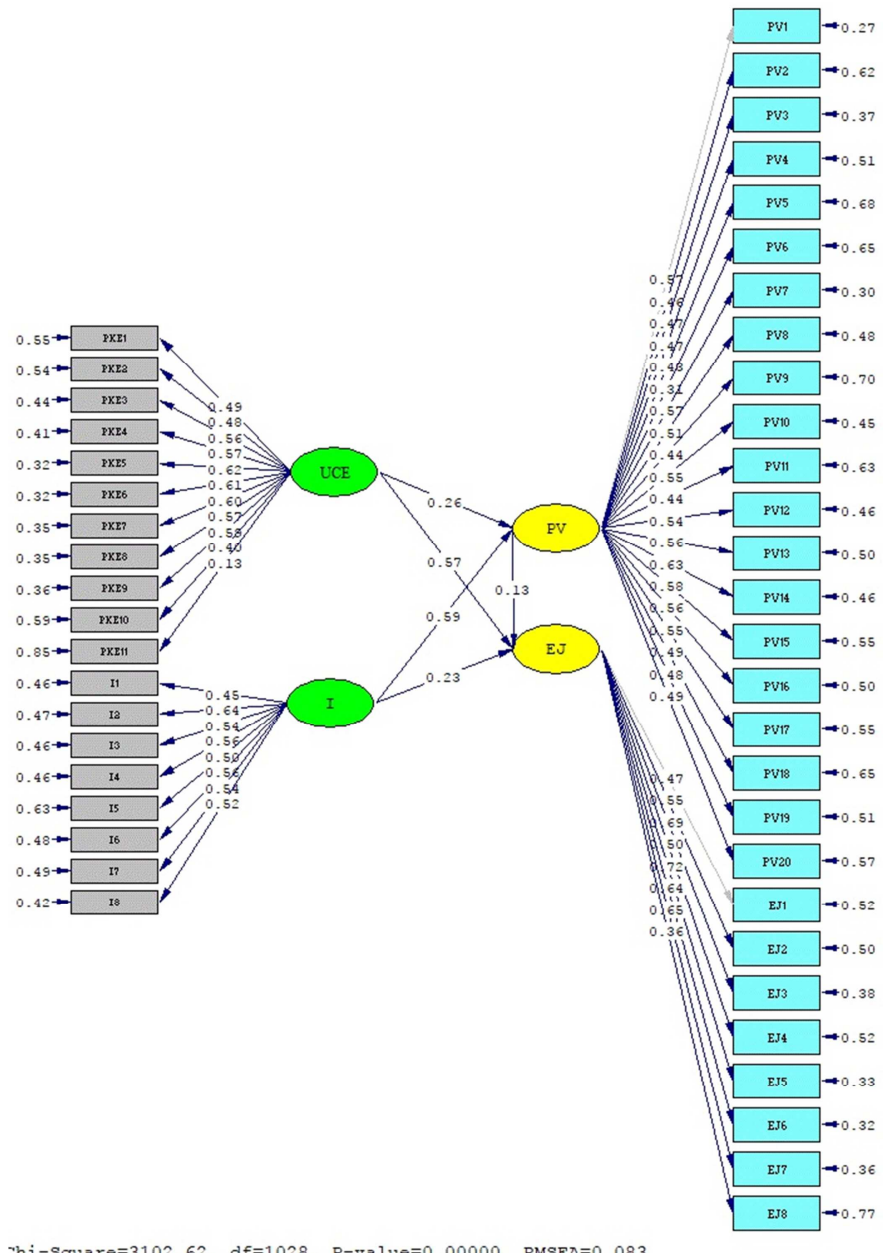

Figure 1. Validity Test. 


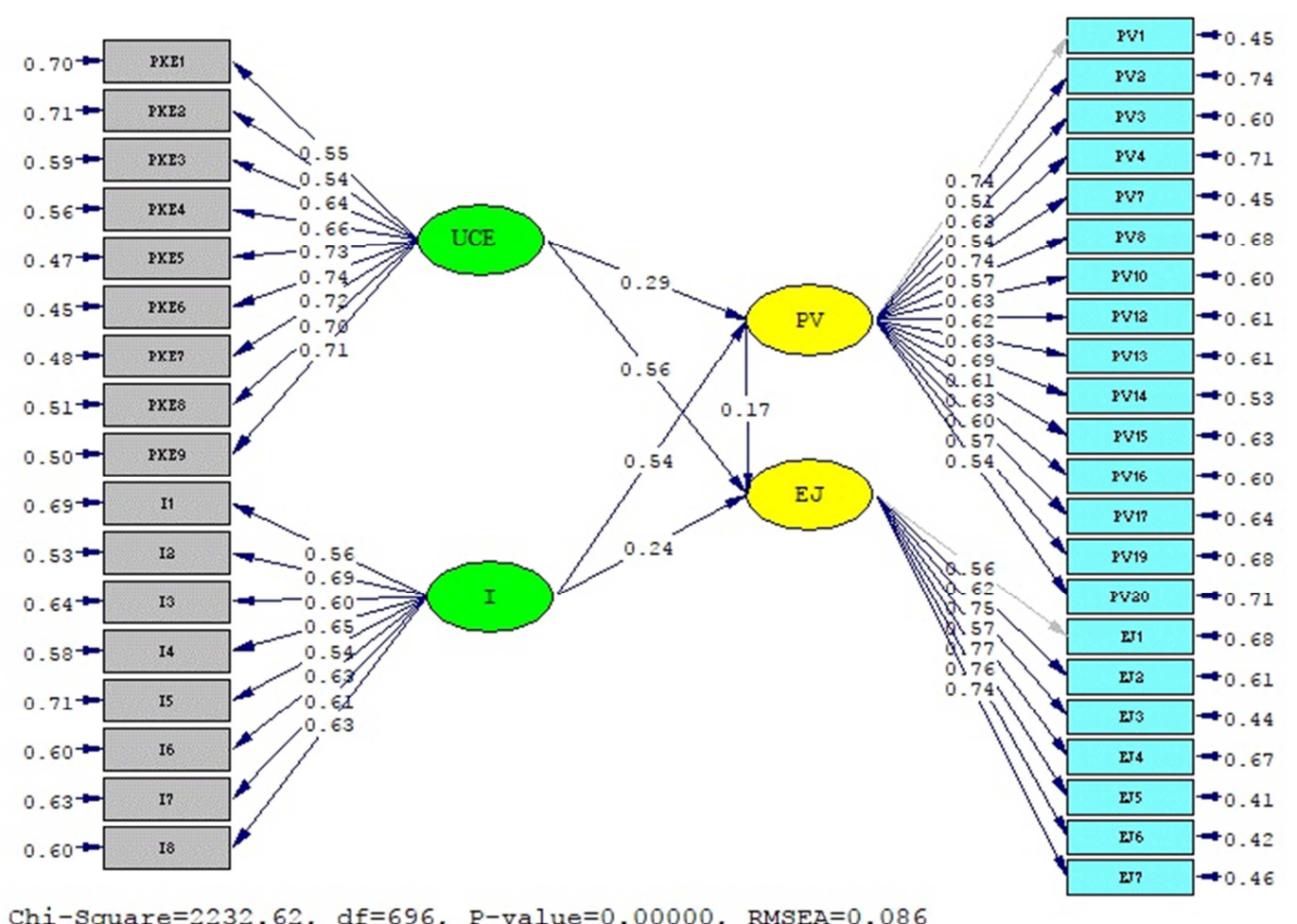

Figure 2. Structural Equation Model.

\subsection{The Understanding Codes of Ethics and Independence Upon the Personal Value}

Based on Figure 1 and 2, standardized Loading Factor and T-Value SEM on each parameter estimate in LISREL 8.72, there are three very useful information, namely regression coefficient, standard error and t value. This structural test can be seen in the multiple regression equation structural equation below:

$$
\mathrm{PV}=0.29 * \mathrm{UCE}+0.55 * \mathrm{I}, \text { Errorvar. }=0.51, \mathrm{R}^{2}=0.49
$$

$$
\begin{array}{ll}
(0.058) & (0.077) \\
4.95 & 8.27
\end{array}
$$

In the first structural equation, it can be seen that the magnitude of the coefficient of determination $\left(R^{2}\right)$ is 0.49 which means that the variables of the Understanding of Code of Ethics (UCE) and Independence (I) can explain the Personal Value (PV) variable by $49 \%$, while the remaining $51 \%$ explained by other factors not contained in the model.

Through the first structural equation can be seen that the relationship between the independent variables Understanding the Code of Ethics (UCE) to Personal Value (PV), has a coefficient of 0.29 and has a t-value of 4.95 (tvalue $>1.96)$. This shows that there is an influence of the Understanding of the Code of Ethics (UCE) on Personal Value (PV). Through this structural equation, it can be seen that the relationship between independence variable (I) to Personal Value (PV) has a coefficient value of 0.54 and has tvalue of 8.27 (t-value $>1,96$ ). This shows that there is influence of Independent (I) on Personal Value (PV).

\subsection{The Understanding Codes of Ethics and Independence Affecting to Ethical Judgement Thru Personal Value Intervention}

In the second structural equation, it can be seen that the magnitude of the coefficient of determination $\left(R^{2}\right)$ is 0.63 which means that the variables of Understanding of Code of Ethics (UCE) and Independence (I) and Personal Value (PV) can explain Ethical Judgement (EJ) variable of $63 \%$, while the remaining $37 \%$ is explained by other factors not contained in the model. The second structural test can be seen in the multiple regression equation structural equation below:

$$
\mathrm{EJ}=0.17 * \mathrm{PV}+0.55 * \mathrm{UCE}+0.24 * \mathrm{I}, \text { Errorvar. }=0.37, \mathrm{R}^{2}=0.63
$$

$\begin{array}{llll}(0.073) & (0.075) & (0.072) & (0,080) \\ 2.31 & 7.10 & 3.30 & 4,67\end{array}$

Through this structural equation it can be seen that the relationship between the Understanding of the Code of Ethics (UCE) to the Ethical Judgement (EJ) has a coefficient value of 0.55 and has a t-value of 7.31 ( $t$-value $>1.96$ ). This indicates that there is an influence of the Understanding Code of Ethics (UCE) to Ethical Judgement (EJ), relationship between of independence (I) to Ethical Judgement (EJ) has a coefficient value of 0.24 and has a t-value of 3.31 ( $\mathrm{t}$-value $>$ $1,96)$, this shows that there is an influence of Independence (I) on Ethical Judgement (EJ), and relationship between Personal Value (PV) to Ethical Judgement (EJ), has a coefficient of 0.17 and has a t-value value of 2.38 (t-value $>$ 1.96), this shows that there is an influence of Personal Value on Ethical Judgement. 
The direct and indirect effect of understanding of code of ethics and independence to ethical judgement through personal value can be calculated by looking at the result of new structural equation, $\mathrm{PV}=0.29 * \mathrm{UCE}+0,54 * \mathrm{I}$, Errorvar $=0.51, \mathrm{R}^{2}=0.49$ and $\mathrm{EJ}=0.17 * \mathrm{PV}+0.55 * \mathrm{UCE}$ $+0.24 * \mathrm{I}$, Errorvar. $=0.37, \mathrm{R}^{2}=0.63$.

The indirect effect of understanding code of ethics on ethical judgements through personal values is 0.05 , ie from $0.29 * 0.17$. Thus, the total effect is 0.60 , ie from the direct effect amount of 0.55 and indirect effect 0.05 . While indirect effect of independence on ethical judgement through personal value is 0.10 , ie from $0.54 * 0.17$. Thus, the total effect is 0.34 , ie the number of direct effects 0.24 and the indirect effects 0.10 .

The equation after the calculation of direct and indirect effects on $\mathrm{EJ}=0.60 * \mathrm{UCE}+0.34 * \mathrm{I}$, Errorvar. $=0.39, \mathrm{R}^{2}=$ 0.61 means that the contribution of each addition of the variable of understanding code of ethics to the ethical judgement through the personal value of 0.60 units. This means that, if there is an addition of a unit of understanding code of ethics, it will affect the increase in ethical judgement by 0.60 units. While contribution of each addition of independent variables to the ethical assessment through personal value of 0.34 units. This means that, if there is an addition of a unit of independence, it will affect an increase in ethical judgement valuation of 0.34 units.

Based on the combined equations, direct and indirect effects, $\mathrm{EJ}=0.60 * \mathrm{UCE}+0.34 * \mathrm{I}$, Errorvar. $=0.39$ and $\mathrm{R}^{2}$ $=0.61$ means that the Indonesian accountant's ethical assessment can be explained by the variables of understanding code of ethics and independence through personal value of $61 \%$ while the remaining $39 \%$ is explained by other variables outside of this model.

\section{Discussion}

\subsection{Main Findings}

1. The understanding codes of ethics has been positively and significantly affecting personal value which is the coefficient value of regression is 0.29 explaining that an increasing of 0.29 of understanding codes of ethics will increase 0.29 of personal value of partners, managers and senior accountant in Indonesia.

2. The independence has significantly and positively affected the personal value which is the coefficient value of regression is 0.55 explaining that each increasing of 0.55 of its independence will increase 0.55 of the personal value of partners, managers and senior accountant in Indonesia.

3. The understanding codes of ethics has been positively affecting ethical judgement which is the determinant coefficient value is 0.55 and errorvar value is 0.55 , it has explained that the personal value of the partners, managers, and senior accountants in Indonesia can be described by the variable of understanding codes of ethics which is 0,55 units.
4. The understanding codes of ethics has positively and significantly affected to ethical judgement which is the coefficient value of regression is 0.24 explaining that a decreasing of understanding codes of ethics will increase ethical judgement of 0.24 units refers to the ethical judgement of partners, managers, and senior accountants in Indonesia.

5. The personal value has positively dan significanly affected to ethical judgement which is the coefficient value of regression is 0,17 . That mean, explaining that 0.17 of increasing of personal value has affected to ethical judgements of the managers and senior accountants in Indonesia.

6. Direct and Indirecteffect understanding code of ethics on ethical judgement through personal value of 0.60 units, means that, if there is addition of one unit of understanding code of ethics, it will affect increase of ethical judgement of 0.60 units and Independence to Ethical Judgement through Personal Value of 0.34. This means that, if there is an addition of one unit of independence, it will affect the increase of ethical judgement of 0.34 units.

Based on above conclusions in particular it can be concluded that the importance of understanding code of ethics, independence, and peronal value for the Indonesian public accountant. During this time no doubt ability of Indonesian accountants in terms of mastery skills in the examination of accounting for the mastery of skills is always done by following various competence tests, training and seminars. But until now there are often fraud committed by some accountants and Public Accounting Firm both in Indonesia and abroad, therefore need to be considered also to be held a test of understanding the code of ethics profession accountant.

\subsection{Limitation}

Some limitations of this research should have to be solved and these limitations can also be used to develop the future similar research. The limitations are as follows;

1. This research has applied the questionnaire which might bias the respondents' responses.

2. This research is focus at the big five of the cities, Jakarta, Bandung, Semarang, Surabaya and Medan. It might be dealing with a different characteristic of the respondents. Therefore, this research can not be generalized for all the accountants in Indonesia.

3. The questionnaire applied is refered to Forsyth and Danisiewics(1985) and Porter et al (1974) related to the independent variable, Massey University New Zealand (2015) related to the personal value variable and Forsyth and Danisiewicz (1985) related to the ethical judgement variable which might be not in compliance with the condition of the accountants in Indonesia.

\section{Conclusion}

The result of this research has indated that the 
understanding codes of ethics has been affecting the personal value and the ethical judgement accordingly. It is expected to provide a positive implication for a public accountant (partner, manager, supervisor and senior accountant) to understand more about the professional codes of ethics. Based on this research, accountants should have understood the professional codes of ethics better. Moreover, they have to improve more their knowledge and to explore more the factors affecting the ethical judgement instead of the variables measured in this research. Therefore, they will be making a judgement based on the better ethical consideration.

\section{References}

[1] Abdolmohammadi, M. J. and C. R. Baker. (2006). Accountants' value preferences and moral reasoning. Journal of Business Ethics, 69 (1): 11-25.

[2] AICPA, (2015). American Institute of Certified Public Accountants, Inc. New York, NY 10036-8775.

[3] Akaah, I. P, and Lund, D. (1994). The influence of personal vand organizational values on marketing professional' ethical behavior, Journal of Business Ethics, Vol 13, pp. 417-30.

[4] Alteer, A. M., Yahya, S. B., dan Haron, M. M. (2013). Auditors' Personal Values And Ethical Judgement At Different Levels Of Ethical Climate: A Conceptual Link, Journal of Asian Scientific Research, 3 (8): 862-875.

[5] Ashbaugh, H; Lafond, R dan Mayhew, B. W. (2003). Do Nonaudit Services Compromise Auditor Independence? Further Evidence. The Accounting Review. 78, (4): 611-639.

[6] Au, A., dan Wong, D. (2000). The impact of guanxi on the ethical decision-making process of auditors - an exploratory study of Chinese CPAs in Hong Kong. Journal of Business Ethics, 28 (11): 87-93.

[7] Booth, Peter dan Schulz, Axel K-D. (2004). The Impact of an Ethical Enviroment on Manager's Project Evaluation Judgment Under Agency Problem Condition, 29 (11):473-488.

[8] Brief, A. P., Dukerich, J. M., Brown, P. R., dan Brett, J. F. (1996). What's Wrong with the Treadway arenCommission Report? Experimental Analyses of the Effects of Personal Values and Codes of Conduct on Fraudulent Financial Reporting, Journal of Business Ethics, 15 (2): 183-198.

[9] Brooks, J. L dan Dunn, P. (2015). Business Ethics and Profession for Director, Executive, and Auditors, Fifth Edition, Book 1\&2, Jakarta: Salemba Empat.

[10] Coleman, M.; Kreuze, J. dan Langsam, S. (2004). The new scarlet letter: Student perceptions of the accounting profession after Enron. Journal of Education for Business, 79 (3), 134141.
[11] Finegan, J. (1994). The impact of personal value on judgements of ethical behavior in the workplace, Journal of Marketing, Vol 49, pp. 87-96.

[12] Ghozali, I dan Fuad. (2005). Structural Equation Modeling: Theory, Concept, and Application with Program Lisrel 8.54, Badan Penerbit Universitas Diponegoro, Semarang.

[13] Herron, T. L. and Gilbertson, D. L. (2004). Ethical principles vs. ethical rules: the moderating of moral development on audit independent judgements. Business Ethics Quarterly, 14 (3): 499-523.

[14] Jones, J; Massey, D. W; and Thorne, L. (2003). Auditors' Ethical Reasoning: Insights From Past Research And Implications For The Future. Journal of Accounting Literature, 22 (11): 45-103.

[15] Jones, T. M. (1991). Ethical decision-making by individuals in organizations: an issue-contingent model, Academy of Management Review, 16, (3): 366-395.

[16] Karacaer, S; Gohar, S; Aygun, M dan Sayin, C. (2009). Effects of personal values on auditor's ethical decisions: A comparison of Pakistani and Turkish professional auditors. Journal of Business Ethics, 88 (1): 53-64.

[17] Krishnamurthy, S; Zhou, J dan Zhou, N. (2002). Auditor Reputation, Auditor Independence and the Stock Market Reaction to Andersen's Clients, School of Management, SUNY - Binghamton University, NY.

[18] Kung, Fan-Hua dan Huang, Cheng Li. (2013). Auditors' moral philosophies and ethica beliefs. Department of Accounting, Tamkang University, Taipei, Taiwan. Management Decision, 51 (3): 479-500.

[19] Muawanah, U. dan N. Indriantoro. (2001). Auditor Behavior in Audit Conflict Situations: The Role of Locus of Control, Professional Commitment and Ethical Awareness, Jurnal Riset Akuntansi Indonesia, 4 (2): 133-150.

[20] Nur, E. D. P; Julita dan Wahyudi, D. P. (2014). The Effect of Ethics, Competency, Auditor Experience, and Audit Situation upon Accuracy of Giving Audit Opinion Through Consideration of Materiality And Skepticism Of Professional Auditors, Jurnal Forum Bisnis dan Kewirausahaan, 3, (3). 116-132.

[21] Pflugrath, G; Bennie, N. M; dan Chen, L. (2007). Causal effects of regulatory, organizational and personal factors on ethical sensitivity, Journal of Business Ethics, 30 (6): 123-59.

[22] Shafer, W. E., Morris, R. E. dan Ketchand, A. A. (2001), Effects of personal values on auditors' ethical decisions, Accounting, Auditing \& Accountability Journal, 14 (3): 25477.

[23] Wright, G. B., Cullinan, C. P. dan Bline, D. M. (1997). The rellationship between an individual's values and perceptions of moral intensity: an empirical study, Behavioral Research in Accounting, 9: 26-40. 